\title{
Models Contribution to the Understanding of Sarcoidosis Pathogenesis: "Are There Good Models of Sarcoidosis?"
}

\author{
Valérie Besnard ${ }^{1, *(1)}$ and Florence Jeny ${ }^{1,2}$ (i) \\ 1 UMR 1272, Hypoxie \& Poumon, Université Sorbonne Paris Nord, 1 rue de Chablis, 93017 Bobigny, France; \\ florence.jeny@aphp.fr \\ 2 AP-HP, Hôpital Avicenne, Service de Pneumologie, 93017 Bobigny, France \\ * Correspondence: valerie.besnard@inserm.fr; Tel.: +33-148-388-877; Fax: +33-148-388-924
}

Received: 8 July 2020; Accepted: 27 July 2020; Published: 31 July 2020

\begin{abstract}
Sarcoidosis is a systemic, granulomatous, and noninfectious disease of unknown etiology. The clinical heterogeneity of the disease (targeted tissue(s), course of the disease, and therapy response) supports the idea that a multiplicity of trigger antigens may be involved. The pathogenesis of sarcoidosis is not yet completely understood, although in recent years, considerable efforts were put to develop novel experimental research models of sarcoidosis. In particular, sarcoidosis patient cells were used within in vitro 3D models to study their characteristics compared to control patients. Likewise, a series of transgenic mouse models were developed to highlight the role of particular signaling pathways in granuloma formation and persistence. The purpose of this review is to put in perspective the contributions of the most recent models in the understanding of sarcoidosis.
\end{abstract}

Keywords: sarcoidosis; models; macrophage; lung; granuloma

\section{Introduction}

Sarcoidosis is a systemic disease of unknown etiology that is characterized by the formation of immune granulomas in different organs, mainly the lungs, the lymphatic system, the skin, the eye, and the heart [1]. The diagnosis consists of the association of compatible clinical, biological, and radiological signs, the histological demonstration of a granuloma characteristic of sarcoidosis, and the elimination of other causes of granulomatosis [2]. Genetically predisposed individuals are exposed to unknown trigger(s), possibly microorganisms, inorganic particles, or other environmental factors that initiate and maintain inflammatory and immune responses. Genetic susceptibility plays an important role in the pathogenesis of sarcoidosis [3]. Recently, nucleotide-binding oligomerization domain 2 NOD2 mutations were involved in the pathogenesis of sarcoidosis, as well as in Blau syndrome (BS) and early onset sarcoidosis (EOS) [4-7]. NOD2 is a cytosolic protein that is involved in microbial cell wall components sensing and inflammation regulation through NFKB activation [8]. In a Swedish study, Rossides et al. showed an increasing risk (3.7 fold) in first-degree relatives of patient with sarcoidosis [9]. Likewise, analysis of a twin cohort revealed an 80 -fold increased risk of developing sarcoidosis compared to the general population [10]. A gene-environment interaction study identified additional genes (FCRL1, IL23R) that could distinguish patients with or without Löfgren's syndrome [11].

The epidemiology and phenotype of sarcoidosis varies highly around the world across age, sex, ethnicity groups, environmental exposure, and socioeconomic status [12-15]. In France, it is an uncommon disease, with a prevalence of 30.2/100,000 people and an incidence of 4.9/100,000 [16]. African Americans and Northern Europeans seem to be the two most affected groups [17,18]. Sarcoidosis incidence and prevalence appear higher in women around the world with some exceptions [19-23]. 
Even if sarcoidosis is considered as a benign disease, it still represents an important issue considering that mortality is higher in patients with sarcoidosis than in the general population with an average age of death of 70.4 versus 76.2 , respectively [9,24]. Mortality rates are also greater in females than males and higher in black than white, Hispanic, or Asian patients [25,26]. Epidemiological studies on sarcoidosis-related mortality and associated morbidities [27] indicated that sarcoidosis patients were high at risk, in particular women, with an average age at death of $70 \pm 13$ years $[24,25]$. In the Western population, deaths are mainly due to fibrotic pulmonary damages, pulmonary hypertension $(\mathrm{PAH})$, and less frequently to cardiac, neurological, and hepatic diseases $[1,28,29]$. The progression of sarcoidosis toward pulmonary fibrosis is considered as an evolutionary turning point that is associated with irreversible sequelae, significant morbidity, and mortality (11.3\% in 7 years) [30].

Sarcoidosis presents a highly variable and unpredictable course. It is estimated that half of patients progress to spontaneous regression within a few years of diagnosis [1]. The treatment of sarcoidosis will be decided when the patient demonstrates an impaired quality of life or when the disease becomes threatening for an organ or the patient's life. Despite the treatment, a significant number of patients will progress to a chronic and progressive form, $10 \%$ to $20 \%$ have sequelae, and mortality is estimated at $6-7 \%$ [1]. To date, there are no reliable markers predicting the progression of the disease [1]. Identifying the molecular mechanisms involved in the disease would help to develop specific treatments for patients who escape the various lines of treatment.

Sarcoidosis is distinct from other granulomatosis by the peculiarity of the granulomas location and distribution [31]. Lymphocyte infiltration and granulomas can be found in the visceral pleura, interlobular septa and bronchovascular vicinities. A mononuclear cell alveolitis induced by an unknown antigen initiates the accumulation of phagocytes that leads to the formation of discrete structures, which are composed of a central core of epithelioid cells surrounded by activated alveolar macrophages and T lymphocytes releasing inflammatory cytokines, including interleukin (IL)- $1 \beta$, IL-12, IL-18, and tumor necrosis factor (TNF)- $\alpha$ [32-35]. The persistence of these structures leads to the formation of non-caseous granulomas with epithelioid cells [27]. Granulomas are composed of a central follicle consisting essentially of macrophages, epithelioid cells associated with giant cells, and CD4 + lymphocytes. The central follicle is surrounded by a lymphocyte crown characterized by the presence of CD8 + lymphocytes, rare B lymphocytes, and a predominance of CD4 + lymphocytes, including Th1, Th2, Th17, and T lymphocytes regulators. As granulomas persist, a lamellar hyaline collagen sclerosis surrounds the various follicles. The origin of cell-constituting granulomas remains uncertain. In tuberculosis, once bacillus phagocytosis by airways macrophages occurred, the infected macrophage may facilitate the spread of disease by migration to distal sites in the lungs. In the parenchyma, infected macrophages recruit uninfected macrophages (intra-alveolar macrophages and monocytes-derived macrophages of systemic origin) to ultimately form a granuloma. A similar process can be hypothesized in sarcoidosis. In the microenvironment of granulomas, intra-alveolar cells are present as a normal or mildly elevated total lymphocyte population, a normal percentage of eosinophils and neutrophils, and an absence of plasma cells and foamy alveolar macrophages [36]. Intra-alveolar monocytes and macrophages are known to feature cells constituting granulomas in the lung, including macrophage-derived epithelioid cells and macrophage-fused multinucleated cells [37].

Research models aim to be isomorphic (replication of pathological and histopathological features), homologous (identification of the pathogenic mechanisms), and predictive (testing of the efficacy and toxicity of potential novel therapeutic strategies). In sarcoidosis, the development of research models was initiated several years ago, with various degrees of success. Mainly in vitro and in vivo models brought some responses at the isomorphic and homologous levels, but they were not predictive yet. Generating sarcoidosis models is crucial considering excess mortality in sarcoidosis and the necessity to understand molecular mechanisms involved in sarcoidosis to develop alternatives therapies to corticotherapy. Developing experimental models is challenging for multiple reasons, including the following reasons: (1) causative agent(s) of the disease are unknown; (2) it is a systemic disease with different targeted organs for each patient and highly diverse presentations; (3) the multiplicity of 
cellular actors and their interactions; (4) genetic variability; and (5) the course of disease resolution is unpredictable amongst patients, indicating the influence of both environmental and genetic factors. Research models were developed using putative sarcoidosis causing agents, either antigens of infectious origin or inorganic particles. Several species of mycobacteria have been implicated as the origin of the immune reaction, notably M. tuberculosis, M. bovis, M. leprae, and M. avium [38]. Exposure to inorganic particles mainly causes foreign body granulomas, such as in models of chronic beryllium disease [39-42] or crystalline silica [43]. Nonetheless, recent epidemiologic and experimental data support the hypothesis on the role of nanoparticles in sarcoidosis [44-50]. In vivo models mostly use mice that do not spontaneously develop sarcoidosis. In veterinary medicine, sarcoidosis is a rare disease. To the best of our knowledge, there are very few publications of animal sarcoidosis [51-54].

The present review is not an exhaustive retrospective of all the literature on experimental granuloma formation, but it aims to put in perspective the contributions of the most recent models in the understanding of sarcoidosis.

\section{In Vitro Models}

So far, in vitro models used peripheral blood mononuclear cells (PBMCs) i.e., a mixed population of peripheral monocytes and lymphocytes reproducing an immune milieu or isolated monocytes derived into differentiated macrophages.

Cultures of PBMCs in the presence of pathogen-coated beads (mostly mycobacterial antigens) generated granulomas-like structures composed of a mix of $\mathrm{CD}_{14}{ }^{+}$monocytes, $\mathrm{CD} 163^{+}$mature macrophages, multinucleated giant cells $\left(\mathrm{CD} 11 \mathrm{~b}^{+}\right)$, and $\mathrm{T}$ and $\mathrm{B}$ lymphocytes (previously reviewed in [55]). Although these models were not sarcoidosis specific, they provided an overview of the kinetics of cell interactions in the formation and progression of granulomas.

The multi-walled carbon nanotubes (MWCT) model was tested using non-adherent murine macrophages in 3D cultures to determine whether granulomas would arise independently of an immune context [56]. Indeed, macrophage differentiation into epithelioid cells and the formation of stable aggregates were induced in response to MWCT exposure. Macrophages presented a phenotypic heterogeneity with the co-expression of M1 and M2 markers (TNF $\alpha$, inducible NO synthase (iNos), and arginase 1 (Arg1) expression).

Very few in vitro models were developed with PBMCs from patients with sarcoidosis. Taflin et al. cultured PBMCs from sarcoidosis patients with sepharose beads coated with $M$. bovis bacillus Calmette-Guérin (BCG) [57]. This study demonstrated the important role of CD25 $5^{\text {high }}$ Treg lymphocytes in granuloma formation $[57,58]$. CD4+CD25 ${ }^{\text {high }}$ FoxP3+ cells exhibited powerful antiproliferative activity, without completely inhibiting TNF- $\alpha$ production, indicating a role for Tregs in suppressing the early stages of autologous granuloma formation. However, functional differences were observed in $\mathrm{CD} 4{ }^{+} \mathrm{CD} 25^{\text {high }}$ cells from healthy subjects compared to those of patients with sarcoidosis. While healthy subjects' $\mathrm{CD} 4^{+} \mathrm{CD} 25^{\text {high }}$ cells accelerated granuloma formation, no changes in the time course of granuloma growth were observed with sarcoidosis patient cells, indicating a defect in the suppressive function of Tregs in sarcoidosis.

Epithelioid cells and multi-nucleated giant cells (MGC) derived from the monocyte-macrophage lineage are the main component cells intervening in the architecture of sarcoidosis granulomas. The differentiation of monocytes into MGC can be induced by various stimuli, including cytokines (IL-3, IFN- $\gamma$ ), growth factors, lectins, and muramyl dipeptide. Monocytes from patients with sarcoidosis stimulated by the supernatant of concanavalin A-stimulated mononuclear cells showed an enhanced potential to form MGCs compared to monocytes from healthy controls or patients with other granulomatous diseases [59]. In the same study, Mizuno et al. showed that MGC formation from macrophages, induced by M-CSF treated-monocytes, was also significantly greater in sarcoidosis patients than in other groups, suggesting that PBMCs in sarcoidosis patients have a propensity to differentiate into MGC in response to inflammatory stimuli. 
Recently, new in vitro models were developed using either PBMCs exposed to purified protein derivative of Mycobacterium tuberculosis (PPD)-coated polystyrene beads, or microparticles generated from Mycobacterium abscessus (MAB) cell walls. After 7 days of culture with the PPD model, granuloma-like multicellular aggregates were formed with the presence of macrophages in the center and peripheral lymphocytes. Crouser et al. showed that macrophages from sarcoidosis patients maintained a M2 phenotype in the presence of PPD beads compared to non-coated beads, compared to control patients for whom macrophages acquired M1 characteristics [60]. Likewise, Locke et al. showed an increase in M2 polarization with the expression of CD163 and an IL13 gene expression profile in sarcoidosis patients compared to control patients in response to PPD beads [61]. In the MAB model, granuloma formation was observed $72 \mathrm{~h}$ after exposure with a marked Th1 and Th17 signature and NFKB activation [62].

The polarization state of macrophages varies in various lung diseases and could depend on signals present within the microenvironment. While macrophage states are globally divided into classically (M1) and alternatively (M2) activated macrophages, their polarization appears as transient and reversible, depending on the milieu $[63,64]$. Data from the literature present different aspects of macrophage polarization in sarcoidosis. Cytokine production in sarcoidosis was initially featured by an increase in Th1 cytokines (IL-2, IL-6, IL-12, IL-18, TNF $\alpha$, IFN $\gamma$ ), which is potentially responsible for the so-called classical (M1) macrophage activation [65-67]. However, studies on marker expression on macrophages gave very opposite results. The gene expression of several M1 and M2 associated markers quantified in cultured total broncho-alveolar lavage (BAL) cells and sorted alveolar macrophages from sarcoidosis patients, with or without Löfgren's syndrome, and compared to healthy subjects did not evidence any differences in alveolar macrophage polarization in sarcoidosis [68]. By contrast, in BAL, M1 macrophages (CD40 hi cells) were increased in sarcoidosis when compared with other ILD, whereas M2 macrophages (CD163 expressing cells) were similar [64]. Likewise, BAL cells from sarcoidosis patients displayed an elevated expression of the transcription factor, Twist1, which is an M1-associated gene compared to healthy controls. The expression of TWIST1 was inducible by M1 activation stimuli (LPS, TNF $\alpha$ ) but not by IL-4 [69]. On the other hand, Prokop et al. identified a dominant Th2 response (IL-4, IL-13, IL-10, DNAX activation protein of 12kDa (DAP12)) with the expression of M2 markers (CD206, CD301, SOCS-1, ARG1, IL-4R, and IL-27R) on macrophages and giant cells in muscle sarcoidosis [70]. Immunohistochemical staining for CD163 expression was significantly increased in sarcoidosis sections compared with those from tuberculosis subjects [71]. Similarly, Isohisa et al. showed an increased immunostaining for CD163 in cutaneous sarcoidosis [72]. Recently, BAL cells from sarcoidosis subjects co-cultured with MSCs showed a reduction in TNF- $\alpha$ (pro-inflammatory M1) and an increase in IL-10 (anti -inflammatory M2) [73]. Obviously, it is quite difficult to establish a real consensus on macrophages polarization in sarcoidosis. There are some variabilities between these studies that need to be taken in consideration: macrophage origins were not always identical (lung versus muscle versus blood), suggesting a possible tissue variability; the local environment was different (PBMCs versus BAL cells versus biopsy samples), possibly affecting cell exposure to a sarcoidosis-causing agent but also the occurrence or not of cell-cell interaction; and experimentally, the culture of macrophages in a culture plate did not recapitulate or even induce phenotype alterations in comparison to macrophages studied ex vivo in a biopsy. One more point to take into account is granuloma dynamics: the structures are not stable and evolved in time for the best (resolution) or the worst (lasting profibrotic granuloma). While biopsies give an instant picture of a pathological process initiated long before, the results of cell cultures are the product of short-term experience at the scale of the formation of a granuloma, probably reflecting the cells and processes set up during granuloma initiation.

\section{In Vivo Models}

In vivo models were developed in mice exposed to putative sarcoidosis-causing agents, either antigens of infectious origin or inorganic particles. In addition, two murine models of transgenic 
mice showed a spontaneous apparition of granulomatous with sarcoidosis-like aspects, indicating the potential role for particular genes/signaling pathways in sarcoidosis.

The two main in vivo models based on infectious agents followed different strategies: the use of mycobacterial antigens without provoking tuberculosis and the exposure to Cutibacterium acnes (C. acnes) (formerly named Propionibacterium acnes, P. acnes), which is a commensal strain of bacteria. Since sarcoidosis patients can be reactive to some mycobacterial proteins (ESAT-6, KatG, Ag85A, SodA, or HSP) [74] and that mycobacteria antigens were detected in sarcoidosis patient granulomas [75-78], models were generated using mycobacterial peptides to study granuloma development in mouse lungs. Peptides from $M$. tuberculosis catalase-peroxidase ( $\mathrm{mKatG}$ ) and $M$. tuberculosis superoxide dismutase A (mSodA) induced pulmonary granulomatosis in mice $[79,80]$. Granulomas were histologically similar to those observed in sarcoidosis with the recruitment of macrophages, $\mathrm{CD}^{+} \mathrm{T}$ lymphocytes with Th1 cytokine (IL-2 and IFN $\gamma$ ) production, and rare B lymphocytes. The presence of serum amyloid A (SAA), a highly inducible acute-phase reactant and amyloid precursor protein, was readily detected in CD68+ macrophages and multi-nucleated giant cells from sarcoidosis patient granulomas in various organs (lung, lymph nodes, skin, liver) and in mycobacterial KatG-bead-induced granulomas in mice [79]. SAA expression appeared to be controlled by the $\mathrm{CD}^{+}$lymphocyte in part through a toll-like receptor 2 TLR2 signaling and correlated with tissue chronic inflammation and fibrosis. Huppertz et al. showed an increased expression of activated NLRP3 (NOD-like receptor (NLR) pyrin domain-containing protein 3) inflammasome components (caspase-1 and IL-1 $\beta$ ) in lung granuloma, and increased IL-1 $\beta$ release of BAL cells from sarcoid patients [81]. In a mouse granuloma model induced by Trehalose 6.6'-dimycolate from Mycobacterium tuberculosis, granuloma formation was decreased in $\mathrm{Nlrp3}^{-{ }^{-}}$mice and increased in miR-223\% (micro-RNA downregulating NLRP3) mice compared to wild-type mice.

The second model used $C$. acnes based on its detection in the lung and lymph nodes of patients $[82,83]$. Several experimental models of $C$. acnes-induced lung granulomatosis were published, each of them with differences in their experimental protocols [84-93]. Granulomas were formed by the recruitment of macrophages and $\mathrm{CD} 4^{+} \mathrm{T}$ and $\mathrm{CD} 45 / \mathrm{B} 220^{+} \mathrm{B}$ lymphocytes promoted by Th1 cytokines and chemokines (TNF $\alpha$, IFN $\gamma, \mathrm{MCP}-1$, IL12p40, and IL12p70) [84-93]. It can be emphasized that the various studies using $C$. acnes to induce pulmonary granulomatosis showed great variability concerning the mode of administration (sub-cutaneous, intravenous, intra-tracheal), the presence or not of adjuvant and the type of adjuvant used (incomplete Freund adjuvant, complete Freund adjuvant), the dose of $C$. acnes, the number of challenges, and the date of sacrifice. Several types of bacterial strains used in these experiments were either commercially provided (ATCC ${ }^{\circledR} 6919$ and ATCC $^{\circledR}$ 11828) [85-92] or from the lymph nodes of sarcoidosis patients [93]. The use of antibiotics targeting endogenous $C$. acnes in mice before immunization decreases pulmonary granulomatosis [92]. Using the C. acnes model, Werner et al. showed that the deletion of Myd88 or Cybb in mice increased the persistence of alive bacteria in the lung and enhanced granuloma formation, indicating that a defect of bacterial clearance through the impairment phagosome activity could participate in granuloma development [93]. As in the model using mKatG [79], the TLR2 response was implicated in granuloma formation induced by C. acnes [94]. Interestingly, Song et al. showed supporting data for the role of Th17 lymphocytes and IL-17A in granuloma formation [95]. C. acnes induction of lung granulomas was reduced in both $I L-17 A$ gene knockout mice and mice receiving an IL-17A neutralizing antibody. To conclude, the difficulties in efficiently reproducing the $C$. acnes-induced pulmonary granulomatosis is probably dependent on the mechanism of repeated antigen recognition and the activation of the CD4 + lymphocyte toward a TH1 phenotype. This mechanism calls upon many factors, which are difficult to control despite the standardization of the conditions of animal facilities. In this sense, this model also responds to the random, multifactorial character described in sarcoidosis.

Based on the possible association between carbon nanoparticles and sarcoid-like pulmonary granulomas, rodent models of chronic granulomatous inflammation were generated by the administration of MWCTs. After pulmonary exposure to MWCTs, a marked inflammatory response was present and associated with the development of granulomas and/or fibrosis $[49,96]$. Depending on 
the physicochemical properties of MWCTs, nanomaterial was detected one year later as black aggregates in macrophages or in granuloma [97]. Yanamala et al. showed distinct and common inflammatory responses to various carbonaceous materials, including MWCTs [98]. Pulmonary granulomas were observed in mice up to 90 days after exposure to the recruitment of $\mathrm{T}$ lymphocytes, macrophages, and the formation of multi-nucleated giant cells [99]. Interestingly, the cytokine expression profile in the MWCT model showed a concomitant expression of Th1 (TNF $\alpha$, IL18), Th2 (CCL7, CCL11), and other cytokines (CCL2, CCL9, CCL22) [99]. In another inorganic particle model using quantum dots (QDOT), particularly QD705, a cadmium-based nanoparticle, lung granulomas were also detected with high expression levels of TNF $\alpha$, IL6, CXCL1, and CCL2 [100]. Comparison of both models showed that although these models were capable of recruiting macrophages, as well as T, B, and Treg lymphocytes, the innate immunity profile and the cytokine production were clearly different, with a more severe inflammation in the QDOT model [101]. Interestingly, Malur et al. showed additive effects on granuloma formation by using a combination of MWCT with microbial antigens (mycobacterial antigen ESAT-6, a T cell activator associated with tuberculosis and sarcoidosis) [102,103]. The double-hit strategy promoted increased granulomas, fibrosis, and inflammatory mediators, indicating that trigger multiplication could be responsible for granuloma persistence associated with pulmonary fibrosis.

In the pathology of sarcoidosis, alterations in circulating lipid levels are observed, notably the reduction in HDL-cholesterol levels and ApoA1 concentrations [104-106]. Similarly, several proteins involved in lipid metabolism, including SAA, plastin 2, fatty acid binding protein 4 , and annexin A2 [107], are expressed differently in patients than in controls. These alterations in lipid metabolism are possibly related to sarcoidosis pathology itself as well as other co-pathologies observed in sarcoidosis, such as the increasing risk of atherosclerosis in patients with sarcoidosis [106,108,109].

IFN $\gamma$ is a key mediator of granuloma formation in sarcoidosis. Barna et al. showed that this cytokine altered the expression of the transcription factor PPAR $\gamma$ (Peroxisome Proliferator-activated Receptor gamma) that controls the transcription of numerous genes implicated in differentiation, proliferation, and apoptosis. PPAR $\gamma$ was reduced in BAL lysates and nuclear PPAR $\gamma$ content in macrophages, suggesting that PPAR $\gamma$ could be an important negative regulator of inflammation in macrophages in sarcoidosis [110]. To demonstrate the role of this transcription factor, Huizar et al. used the MWCT model in mice deleted for Pparg specifically in the myeloid compartment. The loss of PPAR $\gamma$ expression in macrophages promoted a more pronounced granuloma formation and an elevated pro-inflammatory cytokine expression in mice [111]. Using the double hit model (MWCT+ESAT6), Sanderford et al. showed that Pparg deletion in the myeloid compartment favored an increase in the Th1 cell population (Tbet, Stat4, and Ifn $\gamma$ expressing cells), and no changes in the Th2 population in BAL cells [112]. Moreover, Th17 cells (ROR $\gamma \mathrm{t}$, IL17A, CCR6 expressing cells) were recruited in response to an increased expression of IL-6, CCL20. Additional studies demonstrated that cholesterol transporters ABCA1 and ABCG1 expressions were also altered in macrophages from patients with sarcoidosis [113]. Interestingly, the microRNA miR-33, a cholesterol homeostasis regulator, was increased in both BAL cells from MWCNT-instilled mice and patients with sarcoidosis. One direct target of miR-33 is the early B-cell factor 1 (EBF1) that could bind and activate the promoter of master regulators of adipocyte, including CCAAT-enhancer-binding proteins C/EBP $\alpha$ and PPAR $\gamma[114,115]$. However, Barna et al. were not able to show a direct link between miR-33 expression and PPAR $\gamma$ reduction in granuloma macrophages [113].

Previous studies reported an important role of the apolipoprotein ApoE in maintaining normal lung homeostasis during lung development [116] and in response to lung injuries [117-119] by preventing inflammation and oxidative stress caused by hypercholesterolemia. In addition, ApoE enhances host defense to mycobacterial infection by facilitating the presentation of exogenous mycobacterial lipid antigens. After mycobacterial lipid antigens bind ApoE, the complex is internalized via the low density lipoprotein receptor LDLR into antigen-presenting cells, such as dendritic cells and activated human B cells, and then presented by the major histocompatibility complex-like molecule, CD1, to activate NKT cells $[120,121]$. ApoE-deficient mice fed a high-fat diet containing cholate developed sarcoidosis-like 
granulomas without being exposed to any external causing agents [122]. Epithelioid granulomas were observed in the lungs as well as in extrapulmonary locations, including thymus, stomach, liver and skin. Interestingly, fibrotic lesions occurred around granulomas with time, somewhat mimicking a chronic persistent sarcoidosis. Both ApoE deficiency and cholate diet were responsible for granuloma formation, while the high-fat diet alone induced no lesions. Interestingly, ApoE is transcriptionally regulated by PPAR $\gamma$ through an indirect mechanism using a liver $X$ receptorLXR binding site present in an enhancer regulating the ApoE gene [123].

Taken together, these data suggest an important role of lipid metabolism in the regulation of pulmonary inflammation in sarcoidosis. Accumulation of events such as miR-33 presence or the decreased transcriptional activity of PPAR $\gamma$ in sarcoid granuloma macrophages may participate in the promotion of local and systemic dyslipidemia, triggering a persistent inflammatory response.

A second model of transgenic mice spontaneously developing sarcoid-like granulomas was generated with the deletion of the inhibitor tuberous sclerosis complex 2 (Tsc2) in the myeloid lineage in mice. This model demonstrated a major role of a Tsc2 downstream target, rapamycin (mTOR) complex 1 (mTORC1) and its signaling pathway in the initiation and persistence of granulomas [124]. Mice exhibited the spontaneous formation of non-caseating granulomas in multiple organs (lung, skin, ganglion). In these mice, macrophages deficient in $T s c 2$ were hypertrophic, with an increased cell proliferation and a concomitant reduced apoptotic capacity. In parallel, the involvement of mTORC1 activation was found in biopsies of sarcoidosis patients. These results were supported by additional studies showing an increased expression of mTORC1 in cutaneous sarcoidosis patients [125] and an enrichment of the TOR signaling (DDIT4, MLST8, DDIT4L, MTOR) familial cases of sarcoidosis [126]. Interestingly, in a case report of a patient who had developed a systemic de novo sarcoidosis after liver transplantation, the use of rapamune, an immunosuppressor that binds to the specific cytosolic protein FKPB-12 inhibiting mTOR activation, improved dramatically the patient status with both normal chest imaging and liver biopsy [127].

\section{Predictive Models to Test Potential Therapy}

So far, the multiplicity of research model tried to replicate both pathological and histopathological features of sarcoidosis. However, very few were used as a predictive tool to test the toxicity/efficacy of potential new pharmaceutical molecules or combination of existing treatments.

A major predictive model would be to test corticosteroids (CS) resistance. Failure to respond to CS therapy is a common feature of chronical inflammatory diseases, including sarcoidosis, asthma, inflammatory bowel diseases, rheumatoid arthritis, organ transplant rejection, and chemotherapy [128-131]. Mechanisms underlying CS resistance are poorly understood. The effects of CS are mediated by the $C R \alpha$ receptor, whereas the CR $\beta$ displays an inhibitory role [132]. Several lines of evidence suggest that CS resistance could be due to a combination of genetic variations of the $C R \alpha$ receptor, including alterations in its expression levels or activation status [129]. Accumulation of the repressive form CR $\beta$ in response to inflammatory cytokines, including the Macrophage migration inhibitory factor MIF, TNF- $\alpha$, IL-1 $\beta$ IL-8, and IL-2 in association with IL-4, could contribute to reduce CS responsiveness [133-136]. Additionally, an excessive activation of intracellular signaling pathways in response to inflammatory cytokines could reduce CS sensitivity by limiting CR $\alpha$ binding on the glucocorticoid-responsive elements (GREs) of target genes. The formation of CR/STAT5 heterodimers reduced the access to glucocorticoid-responsive elements (GREs) by inhibiting the CR nuclear import, causing steroid insensitivity $[137,138]$. Recently, the role of the Janus kinase/signal transducers and activators of transcription JAK/STAT pathway was associated with the pathogenesis of sarcoidosis [139]. The use of JAK inhibitors was reported to improve significantly sarcoidosis patient status, both at the pulmonary and cutaneous level $[125,140]$. Interestingly, in a specific subset of T-cell acute lymphoblastic leukemia, inhibition of the IL-7 receptor/JAK/STAT signaling by JAK inhibitors treatment enhanced the efficacy of CS by modulating the expression of genes involved in apoptosis [141]. Using research 
models to identify existing or new molecules in combination with CS to re-sensitize sarcoidosis granuloma cells represents a great pharmaceutical challenge.

Recently, Zhang et al. evaluated the anti-inflammatory properties of $\alpha$-melanocyte stimulating hormone $(\alpha-\mathrm{MSH})$ in the MAB model [62]. $\alpha-\mathrm{MSH}$ is a peptide derived from the hormone proopiomelanocortin (POMC), which is capable of reducing inflammation in endotoxin-induced uveitis and in duodenal mucosa in celiac disease patients [142,143]. The binding of $\alpha$-MSH to its receptor, melanocortin receptor (MCR; MC1R and MC5R are expressed by human PBMCs), can downregulate CD86 expression on monocytes and dendritic cells and promote IL-10 release [144-146]. The exposure of MAB induced granulomas to $\alpha$-MSH decreased inflammatory cytokines (II1 $\beta$, Il-8, CCL3, CCL5, IFN $\gamma$, GM-CSF, IL-12) without altering the granuloma structure. Two downstream targets of $\alpha$-MSH appeared to be MARCO, a class A scavenger receptor and the transcription factor CREB. Pathogen Associated Molecular Pattern (PAMPs) recognition and clearing is under the control of both MARCO and TLRs. A reduction of MARCO could decrease granuloma formation. The second target of $\alpha$-MSH is CREB, which is a transcription factor that can be activated by multiple signaling pathways (ERK, PKA, MSK1, JAK/STAT, GSK3b, CAMKII) in response to neurotransmitters, growth factors, ion channels, and inflammatory signals. Interestingly, CREB plays a dual role in immune responses. CREB can induce the transcription of IL-2, IL-6, IL-10, TNF- $\alpha$, COX2, and MIF genes through a CRE element on their promoters. By contrast, CREB can inhibit NFKB activity by competing with CBP/p300 on their common binding site on NFKB $[147,148]$. Unfortunately, Zhang et al. did not evaluate NFkB DNA binding activity to confirm their hypothesis. A third potential target of the anti-inflammatory effects of $\alpha$-MSH could be the JAK/STAT pathway. Indeed, when $\alpha$-MSH binds to its receptor, the JAK2/STAT1 pathway can be activated [149].

Rosiglitazone is a selective nuclear receptor agonist of PPAR $\gamma$ and is an antidiabetic agent of the class of thiazolidinediones. McPeek et al. used rosiglitazone to maintain high alveolar macrophage PPAR $\gamma$ levels in MWCNT-induced pulmonary granulomas. Mice receiving rosiglitazone had lower MWCNT-induced pulmonary granulomas in association with a reduced pro-inflammatory response, and sustained ABCG1 expression in macrophages, supporting the concept that PPAR $\gamma$ deficiency could play a role in sarcoidosis pathogenesis [150].

In a different model of granulomatosis induced by Schistosoma Mansoni infection, Soliman et al. used resveratrol (RSV), a polyphenolic stilbenoid that is present in several plants [151]. Resveratrol can play beneficial roles in chronic diseases related to inflammation, including diabetes, obesity, cardiovascular diseases, and cancers. Resveratrol regulates immunity by interfering with immune cell regulation, reducing oxidative stress, reducing eicosanoids production, and by activating Sirt1, promoting the inhibition of RelA acetylation, which in turn decreases NFKB-induced expression of inflammatory factors such as TNF- $\alpha$, IL- $1 \beta$, IL- 6 , metalloproteases (MMP)- 1 and MMP3, and Cox-2 [152]. Resveratrol treatment of mice infected by Schistosoma Mansoni reduced oxidative stress and the expression of the receptor for advanced glycation end products (RAGE). Interestingly, RAGE is expressed within sarcoidosis granulomas and the SNP-374 T/A polymorphism was associated with the disease [153]. Serum amyloid protein A (SAA) is implicated in sarcoidosis pathology [79,154], and it can bind to RAGE to stimulate sarcoidosis BAL cells to produce pro-inflammatory cytokines $[155,156]$. Testing resveratrol on sarcoidosis models would be of great interest.

Finally, new perspectives of treatment should be considered in regard to the potential role of the NLRP3 inflammasome pathway in sarcoidosis. The use of MCC950, a potent and selective inhibitor of the NLRP3 inflammasome or anti-IL-1 $\beta$ antibody, reduced granuloma formation [81].

\section{5. "Are There Good Models of Sarcoidosis?"}

Actual in vitro and in vivo models seek to understand the pathophysiology of the complex disease that is sarcoidosis. The need for models concerns in particular patients with poor outcomes. Future models should focus on the identification and the understanding of the mechanisms 
influencing the switch between spontaneous sarcoidosis resolution and treatments necessity as well as resistance/insensitivity to treatments.

To date, research models allowed identifying and dissecting some potential interesting actors and their molecular pathways involved in antigen-driven cell aggregation/granuloma formation (Figure 1). We have a better knowledge of some biological pathways involved in granuloma formation and persistence, including macrophage polarization, implication of the mTORC signaling pathway, and the role of lipid metabolism dysregulation [60-62,111-113,124]. The use of human PBMCs from sarcoidosis patients are easily accessible, allow working on various cell populations, and demonstrate that cells have a different phenotype compared to control subjects, suggesting the expression of various genetic variants or acquired traits (epigenetics) in response to peculiar environmental pressure. Models allowed a better comprehension of the role played by the various cell subsets composing granulomas and the cell-cell interactions required to distinguish active versus inactive sarcoidosis, at the exception perhaps of the epithelioid cell population and multinucleated cells in the granuloma core, for which little research has been done so far [59]. Animal models gave more information on the complexity of the different processes, although the "mouse patient" does not always resemble to the "human patient". Notably, transgenic mice are great tools to observe granuloma formation and evolution in response to various triggers in a more physiopathological way. Moreover, the testing of suspect antigens can be evaluated. These models permit also the use of existing treatments (rosiglitazone, rapamycin) to confirm in vivo the potential interest of these molecules in sarcoidosis treatment $[124,150]$.

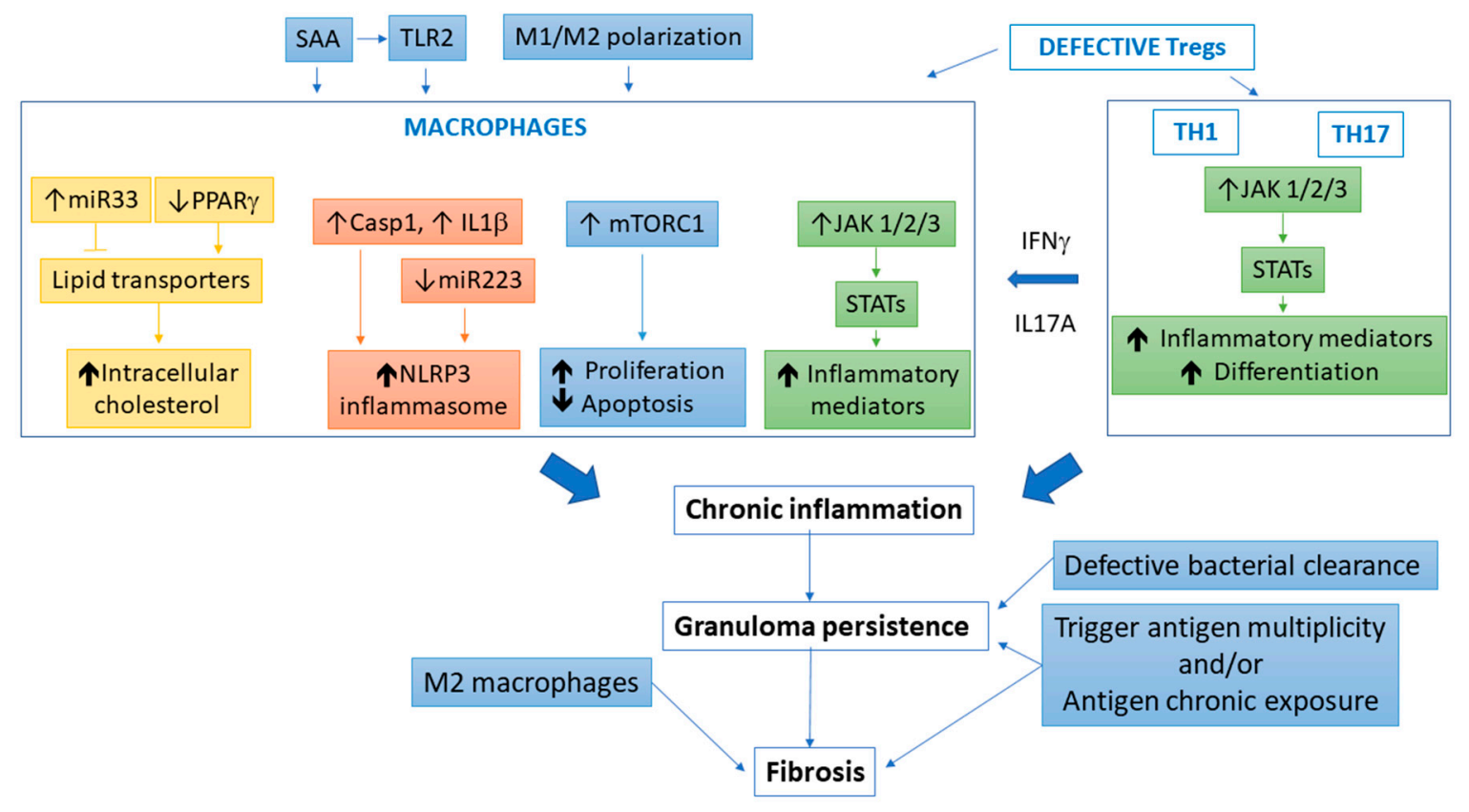

Figure 1. Models contribution to the understanding of sarcoidosis disease progression. In sarcoidosis, an uncontrolled pro-inflammatory phenotype takes place and appears to be amplified by the activation of both extracellular (SAA, macrophage polarization, Treg deficiency) and intracellular (TLR2, lipid metabolism, NLRP3 inflammasome, mTORC1, JAK/STAT) signaling pathways. Activation of these intracellular pathways promotes a chronic inflammatory status of macrophages. The switch "chronic inflammation/granuloma persistence" is probably due to either trigger antigens multiplicity or/and antigen chronic exposure associated with a defect in pathogen clearance. Later, the switch to the M2-like phenotype may participate to initiate or amplify the process of fibrogenesis surrounding granulomas. mTORC1, mammalian/mechanistic target of rapamycin complex 1; PPAR, peroxisome proliferator-activated receptor; SAA, serum amyloid A; TLR, toll-like receptor; Casp1, caspase 1; NLRP3, NOD-like receptor (NLR) pyrin domain-containing protein 3; JAK, Janus kinase; SAA, serum amyloid A; STAT, signal transducers and activators of transcription. 
However, the generation of a valid and widely accepted experimental model that responds to all expectations is probably impossible. Models described so far have a number of weaknesses that would need to be addressed in futures studies:

- No spontaneous in vitro model of granuloma formation exists, and antigenic stimulation is required. Granuloma formation (in vitro and in vivo) is induced in response to agents (bacterial or inorganic origin) that are probably implicated in sarcoidosis, without certainty. In addition, certain models are more representative of foreign body granulomas (nanotube model) than sarcoidosis granulomas.

- No experimental study was done on sarcoidosis patient cells that takes into consideration the epidemiological characteristics of sarcoidosis (age, sex, ethnicity, genetics) to form distinct experimental sub-groups inside the "sarcoidosis group". Exploration of the late stages of the disease is also missing, notably the comparison of different stages of sarcoidosis (persistent versus resolutive, active versus inactive). The generation of cell lines and/or transgenic mice expressing polymorphisms identified in sarcoidosis patients may represent great tools to understand the influence of genetic variants in the pathology.

- In vitro models are short-term studies due to the limited life span of certain cell types.

- Granuloma dynamics cannot be studied in vitro as new cell recruitment from systemic origin does not occur.

- Influence of the local environment (extracellular matrix composition, epithelial and/or mesenchymal crosstalk) remains unknown.

- Murine models of "sarcoidosis-like" granulomatosis present slightly different characteristics in terms of temporality and fibrotic evolution. It is interesting to note that exposure to sarcoidosis-causing agents generates only lung phenotypes, while genetically modified mice developed multiple sites of granulomatosis (lung, skin, liver, stomach, ganglion). In mice, local pulmonary exposure is not sufficient to spread the disease in other physiologic systems, suggesting that either the murine immune system is more efficient than humans to neutralize and eliminate pathogens, or that sarcoidosis patients are chronically exposed to one or multiple triggers, promoting granuloma development and persistence.

- Most in vivo models are restricted to a pulmonary phenotype that does not recapitulate neither the human lung disease (no PAH has been observed) nor certain extrapulmonary lesions (heart, brain, kidney, eye). Notably, no models of cardiac sarcoidosis or neurosarcoidosis exist, although they represent the two more severe organ complications after pulmonary damages.

- $\quad$ Fibrotic lesions were rarely observed in the various in vivo models. In sarcoidosis, fibrosis begins at the periphery of sarcoid active granulomas. Chronic inflammation is probably responsible for fibrosis extension, resulting in larger collagen deposition, and fibroblasts/myofibroblasts differentiation causing parenchymal destruction. Recently, studies have identified several MMPs in BAL fluid and the granulomas of sarcoid patients [157-159], possibly promoting cell migration and extracellular matrix (ECM) remodeling. MMPs are involved in pulmonary fibrosis [160]. The regulation of cytokines such as IL17 and IL22 could influence cell recruitment, granuloma formation, and lung remodeling. Other molecular actors were associated with fibrosis in sarcoidosis (>TGF- $\beta 3$ (rs3917200) [161] >, IL-5 and IL-7 [162]>, S100A9 [163]>). Generating more fibrotic models could be interesting tools to identify key molecules that contribute to the pathophysiology, in order to limit their impact.

- Very few in silico models were proposed so far [164,165]. In silico experimentation involves the combination of biological data and mathematical and computer-based representations to granuloma models. Often, biological data are not sufficient or precise enough to establish proper mathematical models. Carrying computer-based experiments in combination with in vitro/in vivo research could facilitate not only the understanding of the disease but also the testing of new therapeutics. Humanized mice (immunodeficient mice engrafted with functional human cells and 
tissues) are potential preclinical animal models for the study of human diseases. The engraftment of hematopoietic stem cells from sarcoidosis patients would address not only patient uniqueness (age, sex, ethnicity, genetics ... ) but also experimental differences between human and murine immune systems. The engraftment of microdissected human granulomas would allow studying granuloma biodynamics in an in vivo context and potentially drug testing. Ultimately, the use of humanized mice may lead to the achievement of personalized medicine.

\section{Conclusions}

Although a great effort has been put into the development of various sarcoidosis models, there is still a lack of in vitro/in vivo models of sarcoidosis that recapitulate the human disease. A financing program was initiated by the Foundation of Sarcoidosis Research (FSR) to fund research projects developing novel experimental models to explore sarcoidosis pathogenesis and potentially the development of new therapies. Ideally, the molecular features of model granulomas would be conformed with human sarcoidosis tissue granulomas. In addition, the model should be relatively inexpensive, high-throughput, and easily manipulated experimentally. This type of sarcoidosis research model should benefit the testing of new pharmaceutical strategies intended to target a large number of patients. Nowadays, three lines of therapy are sequentially considered $[166,167]$. Corticosteroids are usually the first strategy of choice. When patients are intolerant or develop CS resistance, they can be switched to antimetabolics (methotrexate, azathioprine). When the first two types of treatments fail, anti-TNF- $\alpha$ therapy is considered. The occurrence of relapses on discontinuation or the reduction in treatment is frequent (14\% to $74 \%$ ) [31]. Treatment advances would benefit from innovative research models as revealed with mTOR inhibitors [127]. Alternatively, research models could be developed in order to practice a more "personalized medicine". Testing promising treatments on models from patient PBMCs could help establish a diagnosis based on the uniqueness of each patient and to stop useless, possibly deleterious prescriptions that can be more expensive for public health care.

Author Contributions: V.B. wrote the manuscript. F.J. reviewed and illustrated the manuscript. All authors have read and agreed to the published version of the manuscript.

Funding: This research received no external funding.

Acknowledgments: We thank Carole Planès for fruitful discussions in the course of this work.

Conflicts of Interest: The authors declare no conflict of interest.

\section{References}

1. Valeyre, D.; Prasse, A.; Nunes, H.; Uzunhan, Y.; Brillet, P.Y.; Muller-Quernheim, J. Sarcoidosis. Lancet 2014, 383, 1155-1167. [CrossRef]

2. Crouser, E.D.; Maier, L.A.; Wilson, K.C.; Bonham, C.A.; Morgenthau, A.S.; Patterson, K.C.; Abston, E.; Bernstein, R.C.; Blankstein, R.; Chen, E.S.; et al. Diagnosis and Detection of Sarcoidosis. An Official American Thoracic Society Clinical Practice Guideline. Am. J. Respir. Crit. Care Med. 2020, 201, e26-e51. [CrossRef] [PubMed]

3. Fingerlin, T.E.; Hamzeh, N.; Maier, L.A. Genetics of Sarcoidosis. Clin. Chest. Med. 2015, 36, 569-584. [CrossRef] [PubMed]

4. Besnard, V.; Calender, A.; Bouvry, D.; Pacheco, Y.; Chapelon-Abric, C.; Jeny, F.; Nunes, H.; Planes, C.; Valeyre, D. G908R NOD2 variant in a family with sarcoidosis. Respir. Res. 2018, 19, 44. [CrossRef] [PubMed]

5. Chen, X.; Zhou, Z.; Zhang, Y.; Cheng, X.; Guo, X.; Yang, X. NOD2/CARD15 gene polymorphisms and sarcoidosis susceptibility: Review and meta-analysis. Sarcoidosis Vasc. Diffuse Lung Dis. 2018, 35, 115-122. [PubMed]

6. Caso, F.; Galozzi, P.; Costa, L.; Sfriso, P.; Cantarini, L.; Punzi, L. Autoinflammatory granulomatous diseases: From Blau syndrome and early-onset sarcoidosis to NOD2-mediated disease and Crohn's disease. RMD Open 2015, 1, e000097. [CrossRef] 
7. Rose, C.D.; Pans, S.; Casteels, I.; Anton, J.; Bader-Meunier, B.; Brissaud, P.; Cimaz, R.; Espada, G.; Fernandez-Martin, J.; Hachulla, E.; et al. Blau syndrome: Cross-sectional data from a multicentre study of clinical, radiological and functional outcomes. Rheumatology (Oxford) 2015, 54, 1008-1016. [CrossRef]

8. Ogura, Y.; Bonen, D.K.; Inohara, N.; Nicolae, D.L.; Chen, F.F.; Ramos, R.; Britton, H.; Moran, T.; Karaliuskas, R.; Duerr, R.H.; et al. A frameshift mutation in NOD2 associated with susceptibility to Crohn's disease. Nature 2001, 411, 603-606. [CrossRef]

9. Rossides, M.; Grunewald, J.; Eklund, A.; Kullberg, S.; Di Giuseppe, D.; Askling, J.; Arkema, E.V. Familial aggregation and heritability of sarcoidosis: A Swedish nested case-control study. Eur. Respir. J. 2018, 52. [CrossRef]

10. Sverrild, A.; Backer, V.; Kyvik, K.O.; Kaprio, J.; Milman, N.; Svendsen, C.B.; Thomsen, S.F. Heredity in sarcoidosis: A registry-based twin study. Thorax 2008, 63, 894-896. [CrossRef]

11. Rivera, N.V.; Patasova, K.; Kullberg, S.; Diaz-Gallo, L.M.; Iseda, T.; Bengtsson, C.; Alfredsson, L.; Eklund, A.; Kockum, I.; Grunewald, J.; et al. A Gene-Environment Interaction Between Smoking and Gene polymorphisms Provides a High Risk of Two Subgroups of Sarcoidosis. Sci. Rep. 2019, 9, 18633. [CrossRef] [PubMed]

12. Arkema, E.V.; Grunewald, J.; Kullberg, S.; Eklund, A.; Askling, J. Sarcoidosis incidence and prevalence: A nationwide register-based assessment in Sweden. Eur. Respir. J. 2016, 48, 1690-1699. [CrossRef] [PubMed]

13. Ungprasert, P.; Carmona, E.M.; Utz, J.P.; Ryu, J.H.; Crowson, C.S.; Matteson, E.L. Epidemiology of Sarcoidosis 1946-2013: A Population-Based Study. Mayo Clin. Proc. 2016, 91, 183-188. [CrossRef] [PubMed]

14. Yoon, H.Y.; Kim, H.M.; Kim, Y.J.; Song, J.W. Prevalence and incidence of sarcoidosis in Korea: A nationwide population-based study. Respir. Res. 2018, 19, 158. [CrossRef]

15. Ramos-Casals, M.; Kostov, B.; Brito-Zeron, P.; Siso-Almirall, A.; Baughman, R.P. How the Frequency and Phenotype of Sarcoidosis is Driven by Environmental Determinants. Lung 2019, 197, 427-436. [CrossRef]

16. Duchemann, B.; Annesi-Maesano, I.; Jacobe de Naurois, C.; Sanyal, S.; Brillet, P.Y.; Brauner, M.; Kambouchner, M.; Huynh, S.; Naccache, J.M.; Borie, R.; et al. Prevalence and incidence of interstitial lung diseases in a multi-ethnic county of Greater Paris. Eur. Respir. J. 2017, 50, 1602419. [CrossRef]

17. Bresnitz, E.A.; Strom, B.L. Epidemiology of sarcoidosis. Epidemiol. Rev. 1983, 5, 124-156. [CrossRef]

18. Sharma, O.P. Sarcoidosis around the world. Clin. Chest. Med. 2008, 29, 357-363. [CrossRef]

19. Baughman, R.P.; Field, S.; Costabel, U.; Crystal, R.G.; Culver, D.A.; Drent, M.; Judson, M.A.; Wolff, G. Sarcoidosis in America. Analysis Based on Health Care Use. Ann. Am. Thorac. Soc. 2016, 13, 1244-1252. [CrossRef]

20. Rybicki, B.A.; Maliarik, M.J.; Major, M.; Popovich, J., Jr.; Iannuzzi, M.C. Epidemiology, demographics, and genetics of sarcoidosis. Semin. Respir. Infect. 1998, 13, 166-173.

21. Hillerdal, G.; Nou, E.; Osterman, K.; Schmekel, B. Sarcoidosis: Epidemiology and prognosis. A 15-year European study. Am. Rev. Respir. Dis 1984, 130, 29-32. [PubMed]

22. Byg, K.E.; Milman, N.; Hansen, S. Sarcoidosis in Denmark 1980-1994. A registry-based incidence study comprising 5536 patients. Sarcoidosis Vasc. Diffuse Lung Dis. 2003, 20, 46-52. [PubMed]

23. Kowalska, M.; Niewiadomska, E.; Zejda, J.E. Epidemiology of sarcoidosis recorded in 2006-2010 in the Silesian voivodeship on the basis of routine medical reporting. Ann. Agric. Environ. Med. 2014, 21, 55-58. [PubMed]

24. Jamilloux, Y.; Maucort-Boulch, D.; Kerever, S.; Gerfaud-Valentin, M.; Broussolle, C.; Eb, M.; Valeyre, D.; Seve, P. Sarcoidosis-related mortality in France: A multiple-cause-of-death analysis. Eur. Respir. J. 2016, 48, 1700-1709. [CrossRef] [PubMed]

25. Swigris, J.J.; Olson, A.L.; Huie, T.J.; Fernandez-Perez, E.R.; Solomon, J.; Sprunger, D.; Brown, K.K. Sarcoidosis-related mortality in the United States from 1988 to 2007. Am. J. Respir. Crit. Care Med. 2011, 183, 1524-1530. [CrossRef] [PubMed]

26. Tukey, M.H.; Berman, J.S.; Boggs, D.A.; White, L.F.; Rosenberg, L.; Cozier, Y.C. Mortality among African American women with sarcoidosis: Data from the Black Women's Health Study. Sarcoidosis Vasc. Diffuse Lung Dis. 2013, 30, 128-133. [PubMed]

27. Grunewald, J.; Grutters, J.C.; Arkema, E.V.; Saketkoo, L.A.; Moller, D.R.; Muller-Quernheim, J. Sarcoidosis. Nat. Rev. Dis. Primers 2019, 5, 45. [CrossRef]

28. Baughman, R.P.; Shlobin, O.A.; Wells, A.U.; Alhamad, E.H.; Culver, D.A.; Barney, J.; Cordova, F.C.; Carmona, E.M.; Scholand, M.B.; Wijsenbeek, M.; et al. Clinical features of sarcoidosis associated pulmonary hypertension: Results of a multi-national registry. Respir. Med. 2018, 139, 72-78. [CrossRef] 
29. Boucly, A.; Cottin, V.; Nunes, H.; Jais, X.; Tazi, A.; Prevot, G.; Reynaud-Gaubert, M.; Dromer, C.; Viacroze, C.; Horeau-Langlard, D.; et al. Management and long-term outcomes of sarcoidosis-associated pulmonary hypertension. Eur. Respir. J. 2017, 50, 1700465. [CrossRef]

30. Nardi, A.; Brillet, P.Y.; Letoumelin, P.; Girard, F.; Brauner, M.; Uzunhan, Y.; Naccache, J.M.; Valeyre, D.; Nunes, H. Stage IV sarcoidosis: Comparison of survival with the general population and causes of death. Eur. Respir. J. 2011, 38, 1368-1373. [CrossRef]

31. Statement on Sarcoidosis. Joint Statement of the American Thoracic Society (ATS), the European Respiratory Society (ERS) and the World Association of Sarcoidosis and Other Granulomatous Disorders (WASOG) adopted by the ATS Board of Directors and by the ERS Executive Committee, February 1999. Am. J. Respir. Crit. Care Med. 1999, 160, 736-755.

32. Prasse, A.; Georges, C.G.; Biller, H.; Hamm, H.; Matthys, H.; Luttmann, W.; Virchow, J.C., Jr. Th1 cytokine pattern in sarcoidosis is expressed by bronchoalveolar CD4+ and CD8+ T cells. Clin. Exp. Immunol. 2000, 122, 241-248. [CrossRef]

33. Homolka, J.; Muller-Quernheim, J. Increased interleukin 6 production by bronchoalveolar lavage cells in patients with active sarcoidosis. Lung 1993, 171, 173-183. [CrossRef] [PubMed]

34. Moller, D.R.; Forman, J.D.; Liu, M.C.; Noble, P.W.; Greenlee, B.M.; Vyas, P.; Holden, D.A.; Forrester, J.M.; Lazarus, A.; Wysocka, M.; et al. Enhanced expression of IL-12 associated with Th1 cytokine profiles in active pulmonary sarcoidosis. J. Immunol. 1996, 156, 4952-4960. [PubMed]

35. Shigehara, K.; Shijubo, N.; Ohmichi, M.; Yamada, G.; Takahashi, R.; Okamura, H.; Kurimoto, M.; Hiraga, Y.; Tatsuno, T.; Abe, S.; et al. Increased levels of interleukin-18 in patients with pulmonary sarcoidosis. Am. J. Respir. Crit. Care Med. 2000, 162, 1979-1982. [CrossRef]

36. Drent, M.; Mansour, K.; Linssen, C. Bronchoalveolar lavage in sarcoidosis. Semin. Respir. Crit. Care Med. 2007, 28, 486-495. [CrossRef]

37. van Maarsseveen, T.C.; Vos, W.; van Diest, P.J. Giant cell formation in sarcoidosis: Cell fusion or proliferation with non-division? Clin. Exp. Immunol. 2009, 155, 476-486. [CrossRef]

38. Hu, Y.; Yibrehu, B.; Zabini, D.; Kuebler, W.M. Animal models of sarcoidosis. Cell Tissue Res. 2017, 367, 651-661. [CrossRef]

39. Mayer, A.S.; Hamzeh, N.; Maier, L.A. Sarcoidosis and chronic beryllium disease: Similarities and differences. Semin. Respir. Crit. Care Med. 2014, 35, 316-329. [CrossRef]

40. Votto, J.J.; Barton, R.W.; Gionfriddo, M.A.; Cole, S.R.; McCormick, J.R.; Thrall, R.S. A model of pulmonary granulomata induced by beryllium sulfate in the rat. Sarcoidosis 1987, 4, 71-76.

41. Huang, H.; Meyer, K.C.; Kubai, L.; Auerbach, R. An immune model of beryllium-induced pulmonary granulomata in mice. Histopathology, immune reactivity, and flow-cytometric analysis of bronchoalveolar lavage-derived cells. Lab. Investig. 1992, 67, 138-146. [PubMed]

42. Salehi, F.; Zayed, J.; Audusseau, S.; Muller, C.; Truchon, G.; Plamondon, P.; L'Esperance, G.; Chevalier, G.; Mazer, B. Immunological responses in $\mathrm{C} 3 \mathrm{H} / \mathrm{HeJ}$ mice following nose-only inhalation exposure to different sizes of beryllium metal particles. J. Appl. Toxicol. 2009, 29, 61-68. [CrossRef] [PubMed]

43. Srivastava, K.D.; Rom, W.N.; Jagirdar, J.; Yie, T.A.; Gordon, T.; Tchou-Wong, K.M. Crucial role of interleukin-1beta and nitric oxide synthase in silica-induced inflammation and apoptosis in mice. Am. J. Respir. Crit. Care Med. 2002, 165, 527-533. [CrossRef] [PubMed]

44. Izbicki, G.; Chavko, R.; Banauch, G.I.; Weiden, M.D.; Berger, K.I.; Aldrich, T.K.; Hall, C.; Kelly, K.J.; Prezant, D.J. World Trade Center "sarcoid-like" granulomatous pulmonary disease in New York City Fire Department rescue workers. Chest 2007, 131, 1414-1423. [CrossRef]

45. Girvin, F.; Zeig-Owens, R.; Gupta, D.; Schwartz, T.; Liu, Y.; Weiden, M.D.; Prezant, D.J.; Naidich, D.P. Radiologic Features of World Trade Center-related Sarcoidosis in Exposed NYC Fire Department Rescue Workers. J. Thorac. Imaging 2016, 31, 296-303. [CrossRef]

46. Perlman, S.E.; Friedman, S.; Galea, S.; Nair, H.P.; Eros-Sarnyai, M.; Stellman, S.D.; Hon, J.; Greene, C.M. Short-term and medium-term health effects of 9/11. Lancet 2011, 378, 925-934. [CrossRef]

47. Crowley, L.E.; Herbert, R.; Moline, J.M.; Wallenstein, S.; Shukla, G.; Schechter, C.; Skloot, G.S.; Udasin, I.; Luft, B.J.; Harrison, D.; et al. "Sarcoid like" granulomatous pulmonary disease in World Trade Center disaster responders. Am. J. Ind. Med. 2011, 54, 175-184. [CrossRef] 
48. Wu, M.; Gordon, R.E.; Herbert, R.; Padilla, M.; Moline, J.; Mendelson, D.; Litle, V.; Travis, W.D.; Gil, J. Case report: Lung disease in World Trade Center responders exposed to dust and smoke: Carbon nanotubes found in the lungs of World Trade Center patients and dust samples. Environ. Health Perspect 2010, 118, 499-504. [CrossRef]

49. Muller, J.; Huaux, F.; Moreau, N.; Misson, P.; Heilier, J.F.; Delos, M.; Arras, M.; Fonseca, A.; Nagy, J.B.; Lison, D. Respiratory toxicity of multi-wall carbon nanotubes. Toxicol. Appl. Pharmacol. 2005, 207, 221-231. [CrossRef]

50. Ursini, C.L.; Maiello, R.; Ciervo, A.; Fresegna, A.M.; Buresti, G.; Superti, F.; Marchetti, M.; Iavicoli, S.; Cavallo, D. Evaluation of uptake, cytotoxicity and inflammatory effects in respiratory cells exposed to pristine and -OH and -COOH functionalized multi-wall carbon nanotubes. J. Appl. Toxicol. 2016, 36, $394-403$. [CrossRef]

51. Iyori, K.; Kinoshita, M.; Imai, A.; Imanishi, I.; Shirota, K. Clinical and histopathological presentation and successful treatment with ciclosporin for canine sarcoidosis: A case report. Vet. Dermatol. 2019, 30, 438-e136. [CrossRef] [PubMed]

52. Reijerkerk, E.P.; Veldhuis Kroeze, E.J.; Sloet van Oldruitenborgh-Oosterbaan, M.M. Generalized sarcoidosis in two horses. Tijdschr. Diergeneeskd 2008, 133, 654-661.

53. Oliveira-Filho, J.P.; Monteiro, L.N.; Delfiol, D.J.; Sequeira, J.L.; Amorim, R.M.; Fabris, V.E.; Del Piero, F.; Borges, A.S. Mycobacterium DNA detection in liver and skin of a horse with generalized sarcoidosis. J. Vet. Diagn. Investig. 2012, 24, 596-600. [CrossRef] [PubMed]

54. Woods, L.W.; Johnson, B.; Hietala, S.K.; Galey, F.D.; Gillen, D. Systemic granulomatous disease in a horse grazing pasture containing vetch (Vicia sp.). J. Vet. Diagn Investig. 1992, 4, 356-360. [CrossRef] [PubMed]

55. Jeny, F.; Pacheco, Y.; Besnard, V.; Valeyre, D.; Bernaudin, J.F. Experimental models of sarcoidosis. Curr. Opin. Pulm. Med. 2016, 22, 492-499. [CrossRef]

56. Sanchez, V.C.; Weston, P.; Yan, A.; Hurt, R.H.; Kane, A.B. A 3-dimensional in vitro model of epithelioid granulomas induced by high aspect ratio nanomaterials. Part. Fibre Toxicol. 2011, 8, 17. [CrossRef]

57. Taflin, C.; Miyara, M.; Nochy, D.; Valeyre, D.; Naccache, J.M.; Altare, F.; Salek-Peyron, P.; Badoual, C.; Bruneval, P.; Haroche, J.; et al. FoxP3+ regulatory T cells suppress early stages of granuloma formation but have little impact on sarcoidosis lesions. Am. J. Pathol. 2009, 174, 497-508. [CrossRef]

58. Miyara, M.; Amoura, Z.; Parizot, C.; Badoual, C.; Dorgham, K.; Trad, S.; Kambouchner, M.; Valeyre, D.; Chapelon-Abric, C.; Debre, P.; et al. The immune paradox of sarcoidosis and regulatory T cells. J. Exp. Med. 2006, 203, 359-370. [CrossRef]

59. Mizuno, K.; Okamoto, H.; Horio, T. Heightened ability of monocytes from sarcoidosis patients to form multi-nucleated giant cells in vitro by supernatants of concanavalin A-stimulated mononuclear cells. Clin. Exp. Immunol. 2001, 126, 151-156. [CrossRef]

60. Crouser, E.D.; White, P.; Caceres, E.G.; Julian, M.W.; Papp, A.C.; Locke, L.W.; Sadee, W.; Schlesinger, L.S. A Novel In Vitro Human Granuloma Model of Sarcoidosis and Latent Tuberculosis Infection. Am. J. Respir. Cell Mol. Biol. 2017, 57, 487-498. [CrossRef]

61. Locke, L.W.; Crouser, E.D.; White, P.; Julian, M.W.; Caceres, E.G.; Papp, A.C.; Le, V.T.; Sadee, W.; Schlesinger, L.S. IL-13-regulated Macrophage Polarization during Granuloma Formation in an In Vitro Human Sarcoidosis Model. Am. J. Respir. Cell Mol. Biol. 2019, 60, 84-95. [CrossRef]

62. Zhang, C.; Chery, S.; Lazerson, A.; Altman, N.H.; Jackson, R.; Holt, G.; Campos, M.; Schally, A.V.; Mirsaeidi, M. Anti-inflammatory effects of alpha-MSH through p-CREB expression in sarcoidosis like granuloma model. Sci. Rep. 2020, 10, 7277. [CrossRef]

63. Lescoat, A.; Ballerie, A.; Augagneur, Y.; Morzadec, C.; Vernhet, L.; Fardel, O.; Jego, P.; Jouneau, S.; Lecureur, V. Distinct Properties of Human M-CSF and GM-CSF Monocyte-Derived Macrophages to Simulate Pathological Lung Conditions In Vitro: Application to Systemic and Inflammatory Disorders with Pulmonary Involvement. Int. J. Mol. Sci. 2018, 19, 894. [CrossRef] [PubMed]

64. Wojtan, P.; Mierzejewski, M.; Osinska, I.; Domagala-Kulawik, J. Macrophage polarization in interstitial lung diseases. Cent. Eur. J. Immunol. 2016, 41, 159-164. [CrossRef] [PubMed]

65. Grunewald JEklund, A. Role of CD4+ T cells in sarcoidosis. Proc. Am. Thorac. Soc. 2007, 4, 461-464. [CrossRef] [PubMed]

66. Agostini, C.; Adami, F.; Semenzato, G. New pathogenetic insights into the sarcoid granuloma. Curr. Opin. Rheumatol. 2000, 12, 71-76. [CrossRef] [PubMed] 
67. Ziegenhagen, M.W.; Muller-Quernheim, J. The cytokine network in sarcoidosis and its clinical relevance. J. Intern. Med. 2003, 253, 18-30. [CrossRef] [PubMed]

68. Wiken, M.; Idali, F.; Al Hayja, M.A.; Grunewald, J.; Eklund, A.; Wahlstrom, J. No evidence of altered alveolar macrophage polarization, but reduced expression of TLR2, in bronchoalveolar lavage cells in sarcoidosis. Respir. Res. 2010, 11, 121. [CrossRef]

69. Barna, B.P.; Huizar, I.; Malur, A.; McPeek, M.; Marshall, I.; Jacob, M.; Dobbs, L.; Kavuru, M.S.; Thomassen, M.J. Carbon nanotube-induced pulmonary granulomatous disease: Twist1 and alveolar macrophage M1 activation. Int. J. Mol. Sci. 2013, 14, 23858-23871. [CrossRef]

70. Prokop, S.; Heppner, F.L.; Goebel, H.H.; Stenzel, W. M2 polarized macrophages and giant cells contribute to myofibrosis in neuromuscular sarcoidosis. Am. J. Pathol. 2011, 178, 1279-1286. [CrossRef]

71. Shamaei, M.; Mortaz, E.; Pourabdollah, M.; Garssen, J.; Tabarsi, P.; Velayati, A.; Adcock, I.M. Evidence for M2 macrophages in granulomas from pulmonary sarcoidosis: A new aspect of macrophage heterogeneity. Hum. Immunol. 2018, 79, 63-69. [CrossRef] [PubMed]

72. Isohisa, T.; Asai, J.; Kanemaru, M.; Arita, T.; Tsutsumi, M.; Kaneko, Y.; Arakawa, Y.; Wada, M.; Konishi, E.; Katoh, N. CD163-positive macrophage infiltration predicts systemic involvement in sarcoidosis. J. Cutan. Pathol. 2020. [CrossRef] [PubMed]

73. McClain Caldwell, I.; Hogden, C.; Nemeth, K.; Boyajian, M.; Krepuska, M.; Szombath, G.; MacDonald, S.; Abshari, M.; Moss, J.; Vitale-Cross, L.; et al. Bone Marrow-Derived Mesenchymal Stromal Cells (MSCs) Modulate the Inflammatory Character of Alveolar Macrophages from Sarcoidosis Patients. J. Clin. Med. 2020, 9, 278. [CrossRef] [PubMed]

74. Oswald-Richter, K.A.; Beachboard, D.C.; Zhan, X.; Gaskill, C.F.; Abraham, S.; Jenkins, C.; Culver, D.A.; Drake, W. Multiple mycobacterial antigens are targets of the adaptive immune response in pulmonary sarcoidosis. Respir. Res. 2010, 11, 161. [CrossRef] [PubMed]

75. Song, Z.; Marzilli, L.; Greenlee, B.M.; Chen, E.S.; Silver, R.F.; Askin, F.B.; Teirstein, A.S.; Zhang, Y.; Cotter, R.J.; Moller, D.R. Mycobacterial catalase-peroxidase is a tissue antigen and target of the adaptive immune response in systemic sarcoidosis. J. Exp. Med. 2005, 201, 755-767. [CrossRef]

76. Dubaniewicz, A.; Dubaniewicz-Wybieralska, M.; Sternau, A.; Zwolska, Z.; Izycka-Swieszewska, E.; Augustynowicz-Kopec, E.; Skokowski, J.; Singh, M.; Zimnoch, L. Mycobacterium tuberculosis complex and mycobacterial heat shock proteins in lymph node tissue from patients with pulmonary sarcoidosis. J. Clin. Microbiol. 2006, 44, 3448-3451. [CrossRef]

77. Drake, W.P.; Dhason, M.S.; Nadaf, M.; Shepherd, B.E.; Vadivelu, S.; Hajizadeh, R.; Newman, L.S.; Kalams, S.A. Cellular recognition of Mycobacterium tuberculosis ESAT-6 and KatG peptides in systemic sarcoidosis. Infect. Immun. 2007, 75, 527-530. [CrossRef]

78. Chen, E.S.; Wahlstrom, J.; Song, Z.; Willett, M.H.; Wiken, M.; Yung, R.C.; West, E.E.; McDyer, J.F.; Zhang, Y.; Eklund, A.; et al. T cell responses to mycobacterial catalase-peroxidase profile a pathogenic antigen in systemic sarcoidosis. J. Immunol. 2008, 181, 8784-8796. [CrossRef]

79. Chen, E.S.; Song, Z.; Willett, M.H.; Heine, S.; Yung, R.C.; Liu, M.C.; Groshong, S.D.; Zhang, Y.; Tuder, R.M.; Moller, D.R. Serum amyloid A regulates granulomatous inflammation in sarcoidosis through Toll-like receptor-2. Am. J. Respir. Crit. Care Med. 2010, 181, 360-373. [CrossRef]

80. Swaisgood, C.M.; Oswald-Richter, K.; Moeller, S.D.; Klemenc, J.M.; Ruple, L.M.; Farver, C.F.; Drake, J.M.; Culver, D.A.; Drake, W.P. Development of a sarcoidosis murine lung granuloma model using Mycobacterium superoxide dismutase A peptide. Am. J. Respir. Cell Mol. Biol. 2011, 44, 166-174. [CrossRef]

81. Huppertz, C.; Jager, B.; Wieczorek, G.; Engelhard, P.; Oliver, S.J.; Bauernfeind, F.G.; Littlewood-Evans, A.; Welte, T.; Hornung, V.; Prasse, A. The NLRP3 inflammasome pathway is activated in sarcoidosis and involved in granuloma formation. Eur. Respir. J. 2020, 55. [CrossRef] [PubMed]

82. Ishige, I.; Eishi, Y.; Takemura, T.; Kobayashi, I.; Nakata, K.; Tanaka, I.; Nagaoka, S.; Iwai, K.; Watanabe, K.; Takizawa, T.; et al. Propionibacterium acnes is the most common bacterium commensal in peripheral lung tissue and mediastinal lymph nodes from subjects without sarcoidosis. Sarcoidosis Vasc. Diffuse Lung Dis. 2005, 22, 33-42. [PubMed]

83. Negi, M.; Takemura, T.; Guzman, J.; Uchida, K.; Furukawa, A.; Suzuki, Y.; Iida, T.; Ishige, I.; Minami, J.; Yamada, T.; et al. Localization of propionibacterium acnes in granulomas supports a possible etiologic link between sarcoidosis and the bacterium. Mod. Pathol. 2012, 25, 1284-1297. [CrossRef] [PubMed] 
84. Ichiyasu, H.; Suga, M.; Iyonaga, K.; Ando, M. Role of monocyte chemoattractant protein-1 in Propionibacterium acnes-induced pulmonary granulomatosis. Microsc. Res. Technol. 2001, 53, $288-297$. [CrossRef]

85. Iio, K.; Iio, T.U.; Okui, Y.; Ichikawa, H.; Tanimoto, Y.; Miyahara, N.; Kanehiro, A.; Tanimoto, M.; Nakata, Y.; Kataoka, M. Experimental pulmonary granuloma mimicking sarcoidosis induced by Propionibacterium acnes in mice. Acta Med. Okayama 2010, 64, 75-83.

86. Itakura, M.; Tokuda, A.; Kimura, H.; Nagai, S.; Yoneyama, H.; Onai, N.; Ishikawa, S.; Kuriyama, T.; Matsushima, K. Blockade of secondary lymphoid tissue chemokine exacerbates Propionibacterium acnes-induced acute lung inflammation. J. Immunol. 2001, 166, 2071-2079. [CrossRef]

87. Jiang, D.; Huang, X.; Geng, J.; Dong, R.; Li, S.; Liu, Z.; Wang, C.; Dai, H. Pulmonary fibrosis in a mouse model of sarcoid granulomatosis induced by booster challenge with Propionibacterium acnes. Oncotarget 2016, 7, 33703-33714. [CrossRef]

88. Kamata, M.; Tada, Y.; Mitsui, A.; Shibata, S.; Miyagaki, T.; Asano, Y.; Sugaya, M.; Kadono, T.; Sato, S. ICAM-1 deficiency exacerbates sarcoid-like granulomatosis induced by Propionibacterium acnes through impaired IL-10 production by regulatory T cells. Am. J. Pathol. 2013, 183, 1731-1739. [CrossRef]

89. Kishi, J.; Nishioka, Y.; Kuwahara, T.; Kakiuchi, S.; Azuma, M.; Aono, Y.; Makino, H.; Kinoshita, K.; Kishi, M.; Batmunkh, R.; et al. Blockade of Th1 chemokine receptors ameliorates pulmonary granulomatosis in mice. Eur. Respir. J. 2011, 38, 415-424. [CrossRef]

90. McCaskill, J.G.; Chason, K.D.; Hua, X.; Neuringer, I.P.; Ghio, A.J.; Funkhouser, W.K.; Tilley, S.L. Pulmonary immune responses to Propionibacterium acnes in C57BL/6 and BALB/c mice. Am. J. Respir. Cell Mol. Biol. 2006, 35, 347-356. [CrossRef]

91. Minami, J.; Eishi, Y.; Ishige, Y.; Kobayashi, I.; Ishige, I.; Kobayashi, D.; Ando, N.; Uchida, K.; Ikeda, S.; Sorimachi, N.; et al. Pulmonary granulomas caused experimentally in mice by a recombinant trigger-factor protein of Propionibacterium acnes. J. Med. Dent. Sci. 2003, 50, 265-274.

92. Nishiwaki, T.; Yoneyama, H.; Eishi, Y.; Matsuo, N.; Tatsumi, K.; Kimura, H.; Kuriyama, T.; Matsushima, K. Indigenous pulmonary Propionibacterium acnes primes the host in the development of sarcoid-like pulmonary granulomatosis in mice. Am. J. Pathol. 2004, 165, 631-639. [CrossRef]

93. Werner, J.L.; Escolero, S.G.; Hewlett, J.T.; Mak, T.N.; Williams, B.P.; Eishi, Y.; Nunez, G. Induction of Pulmonary Granuloma Formation by Propionibacterium acnes Is Regulated by MyD88 and Nox2. Am. J. Respir. Cell Mol. Biol. 2017, 56, 121-130. [CrossRef] [PubMed]

94. Gabrilovich, M.I.; Walrath, J.; van Lunteren, J.; Nethery, D.; Seifu, M.; Kern, J.A.; Harding, C.V.; Tuscano, L.; Lee, H.; Williams, S.D.; et al. Disordered Toll-like receptor 2 responses in the pathogenesis of pulmonary sarcoidosis. Clin. Exp. Immunol. 2013, 173, 512-522. [CrossRef] [PubMed]

95. Song, J.; Zhao, M.; Li, Q.; Lu, L.; Zhou, Y.; Zhang, Y.; Chen, T.; Tang, D.; Zhou, N.; Yin, C.; et al. IL-17A Can Promote Propionibacterium acnes-Induced Sarcoidosis-Like Granulomatosis in Mice. Front. Immunol. 2019, 10, 1923. [CrossRef] [PubMed]

96. Dong, J.; Porter, D.W.; Batteli, L.A.; Wolfarth, M.G.; Richardson, D.L.; Ma, Q. Pathologic and molecular profiling of rapid-onset fibrosis and inflammation induced by multi-walled carbon nanotubes. Arch. Toxicol. 2015, 89, 621-633. [CrossRef]

97. Knudsen, K.B.; Berthing, T.; Jackson, P.; Poulsen, S.S.; Mortensen, A.; Jacobsen, N.R.; Skaug, V.; Szarek, J.; Hougaard, K.S.; Wolff, H.; et al. Physicochemical predictors of Multi-Walled Carbon Nanotube-induced pulmonary histopathology and toxicity one year after pulmonary deposition of 11 different Multi-Walled Carbon Nanotubes in mice. Basic Clin. Pharmacol. Toxicol. 2019, 124, 211-227. [CrossRef]

98. Yanamala, N.; Desai, I.C.; Miller, W.; Kodali, V.K.; Syamlal, G.; Roberts, J.R.; Erdely, A.D. Grouping of carbonaceous nanomaterials based on association of patterns of inflammatory markers in BAL fluid with adverse outcomes in lungs. Nanotoxicology 2019, 13, 1102-1116. [CrossRef]

99. Huizar, I.; Malur, A.; Midgette, Y.A.; Kukoly, C.; Chen, P.; Ke, P.C.; Podila, R.; Rao, A.M.; Wingard, C.J.; Dobbs, L.; et al. Novel murine model of chronic granulomatous lung inflammation elicited by carbon nanotubes. Am. J. Respir. Cell Mol. Biol. 2011, 45, 858-866. [CrossRef]

100. Ho, C.C.; Chang, H.; Tsai, H.T.; Tsai, M.H.; Yang, C.S.; Ling, Y.C.; Lin, P. Quantum dot 705, a cadmium-based nanoparticle, induces persistent inflammation and granuloma formation in the mouse lung. Nanotoxicology 2013, 7, 105-115. [CrossRef] 
101. Pacheco, Y.; Ponchon, M.; Lebecque, S.; Calender, A.; Bernaudin, J.F.; Valeyre, D.; Iglarz, M.; Strasser, D.S.; Studer, R.; Freti, D.; et al. Granulomatous lung inflammation is nanoparticle type-dependent. Exp. Lung Res. 2018, 44, 25-39. [CrossRef] [PubMed]

102. Malur, A.; Barna, B.P.; Patel, J.; McPeek, M.; Wingard, C.J.; Dobbs, L.; Thomassen, M.J. Exposure to a Mycobacterial Antigen, ESAT-6, Exacerbates Granulomatous and Fibrotic Changes in a Multiwall Carbon Nanotube Model of Chronic Pulmonary Disease. J. Nanomed Nanotechnol. 2015, 6. [CrossRef]

103. Malur, A.; Mohan, A.; Barrington, R.A.; Leffler, N.; Muller-Borer, B.; Murray, G.; Kew, K.; Zhou, C.; Russell, J.; Jones, J.L.; et al. Peroxisome Proliferator-activated Receptor-gamma Deficiency Exacerbates Fibrotic Response to Mycobacteria Peptide in Murine Sarcoidosis Model. Am. J. Respir. Cell Mol. Biol. 2019, 61, 198-208. [CrossRef] [PubMed]

104. Psathakis, K.; Papatheodorou, G.; Plataki, M.; Panagou, P.; Loukides, S.; Siafakas, N.M.; Bouros, D. 8-Isoprostane, a marker of oxidative stress, is increased in the expired breath condensate of patients with pulmonary sarcoidosis. Chest 2004, 125, 1005-1011. [CrossRef] [PubMed]

105. Andreassen, O.A.; Desikan, R.S.; Wang, Y.; Thompson, W.K.; Schork, A.J.; Zuber, V.; Doncheva, N.T.; Ellinghaus, E.; Albrecht, M.; Mattingsdal, M.; et al. Abundant genetic overlap between blood lipids and immune-mediated diseases indicates shared molecular genetic mechanisms. PLoS ONE 2015, 10, e0123057.

106. Salazar, A.; Mana, J.; Pinto, X.; Argimon, J.M.; Castineiras, M.J.; Fiol, C.; Pujol, R. Low levels of high density lipoprotein cholesterol in patients with active sarcoidosis. Atherosclerosis 1998, 136, 133-137. [CrossRef]

107. Landi, C.; Bargagli, E.; Carleo, A.; Bianchi, L.; Gagliardi, A.; Cillis, G.; Perari, M.G.; Refini, R.M.; Prasse, A.; Bini, L.; et al. A functional proteomics approach to the comprehension of sarcoidosis. J. Proteom. 2015, 128, 375-387. [CrossRef]

108. Kindman, L.A.; Gilbert, H.S.; Almenoff, J.S.; Ginsberg, H.; Fagerstrom, R.; Teirstein, A.S. High-density lipoprotein cholesterol is reduced in patients with sarcoidosis. Am. J. Med. 1989, 86, 376-378. [CrossRef]

109. Simonen, P.; Lehtonen, J.; Gylling, H.; Kupari, M. Cholesterol metabolism in cardiac sarcoidosis. Atherosclerosis 2016, 248, 210-215. [CrossRef]

110. Barna, B.P.; Culver, D.A.; Abraham, S.; Malur, A.; Bonfield, T.L.; John, N.; Farver, C.F.; Drazba, J.A.; Raychaudhuri, B.; Kavuru, M.S.; et al. Depressed peroxisome proliferator-activated receptor gamma (PPargamma) is indicative of severe pulmonary sarcoidosis: Possible involvement of interferon gamma (IFN-gamma). Sarcoidosis Vasc. Diffuse Lung Dis. 2006, 23, 93-100.

111. Huizar, I.; Malur, A.; Patel, J.; McPeek, M.; Dobbs, L.; Wingard, C.; Barna, B.P.; Thomassen, M.J. The role of PPARgamma in carbon nanotube-elicited granulomatous lung inflammation. Respir. Res. 2013, $14,7$. [CrossRef]

112. Sanderford, V.; Barna, B.P.; Barrington, R.A.; Malur, A.; Mohan, A.; Leffler, N.; Soliman, E.; Thomassen, M.J. PPARgamma Deficiency in Carbon Nanotube-elicited Granulomatous Inflammation Promotes a Th17 Response to a Microbial Antigen. J. Nanomed Nanotechnol. 2020, 11. [CrossRef] [PubMed]

113. Barna, B.P.; McPeek, M.; Malur, A.; Fessler, M.B.; Wingard, C.J.; Dobbs, L.; Verbanac, K.M.; Bowling, M.; Judson, M.A.; Thomassen, M.J. Elevated MicroRNA-33 in Sarcoidosis and a Carbon Nanotube Model of Chronic Granulomatous Disease. Am. J. Respir. Cell Mol. Biol. 2016, 54, 865-871. [CrossRef] [PubMed]

114. Jimenez, M.A.; Akerblad, P.; Sigvardsson, M.; Rosen, E.D. Critical role for Ebf1 and Ebf2 in the adipogenic transcriptional cascade. Mol. Cell Biol. 2007, 27, 743-757. [CrossRef] [PubMed]

115. Taniguchi, M.; Nakajima, I.; Chikuni, K.; Kojima, M.; Awata, T.; Mikawa, S. MicroRNA-33b downregulates the differentiation and development of porcine preadipocytes. Mol. Biol. Rep. 2014, 41, 1081-1090. [CrossRef] [PubMed]

116. Massaro, D.; Massaro, G.D. Apoetm1Unc mice have impaired alveologenesis, low lung function, and rapid loss of lung function. Am. J. Physiol. Lung Cell Mol. Physiol. 2008, 294, L991-L997. [CrossRef]

117. Goldklang, M.; Golovatch, P.; Zelonina, T.; Trischler, J.; Rabinowitz, D.; Lemaitre, V.; D'Armiento, J. Activation of the TLR4 signaling pathway and abnormal cholesterol efflux lead to emphysema in ApoE-deficient mice. Am. J. Physiol. Lung Cell Mol. Physiol. 2012, 302, L1200-L1208. [CrossRef]

118. Ouyang, Q.; Huang, Z.; Lin, H.; Ni, J.; Lu, H.; Chen, X.; Wang, Z.; Lin, L. Apolipoprotein E deficiency and high-fat diet cooperate to trigger lipidosis and inflammation in the lung via the toll-like receptor 4 pathway. Mol. Med. Rep. 2015, 12, 2589-2597. [CrossRef] 
119. Hansmann, G.; Wagner, R.A.; Schellong, S.; Perez, V.A.; Urashima, T.; Wang, L.; Sheikh, A.Y.; Suen, R.S.; Stewart, D.J.; Rabinovitch, M. Pulmonary arterial hypertension is linked to insulin resistance and reversed by peroxisome proliferator-activated receptor-gamma activation. Circulation 2007, 115, 1275-1284. [CrossRef]

120. van den Elzen, P.; Garg, S.; Leon, L.; Brigl, M.; Leadbetter, E.A.; Gumperz, J.E.; Dascher, C.C.; Cheng, T.Y.; Sacks, F.M.; Illarionov, P.A.; et al. Apolipoprotein-mediated pathways of lipid antigen presentation. Nature 2005, 437, 906-910. [CrossRef]

121. Allan, L.L.; Hoefl,K.; Zheng, D.J.; Chung, B.K.; Kozak, F.K.; Tan, R.; van den Elzen, P. Apolipoprotein-mediated lipid antigen presentation in B cells provides a pathway for innate help by NKT cells. Blood 2009, 114, 2411-2416. [CrossRef]

122. Samokhin, A.O.; Buhling, F.; Theissig, F.; Bromme, D. ApoE-deficient mice on cholate-containing high-fat diet reveal a pathology similar to lung sarcoidosis. Am. J. Pathol. 2010, 176, 1148-1156. [CrossRef]

123. Yue LMazzone, T. Peroxisome proliferator-activated receptor \{gamma\} stimulation of adipocyte ApoE gene transcription mediated by the liver receptor X pathway. J. Biol. Chem. 2009, 284, 10453-10461.

124. Linke, M.; Pham, H.T.; Katholnig, K.; Schnoller, T.; Miller, A.; Demel, F.; Schutz, B.; Rosner, M.; Kovacic, B.; Sukhbaatar, N.; et al. Chronic signaling via the metabolic checkpoint kinase mTORC1 induces macrophage granuloma formation and marks sarcoidosis progression. Nat. Immunol. 2017, 18, 293-302. [CrossRef] [PubMed]

125. Damsky, W.; Thakral, D.; Emeagwali, N.; Galan, A.; King, B. Tofacitinib Treatment and Molecular Analysis of Cutaneous Sarcoidosis. N. Engl. J. Med. 2018, 379, 2540-2546. [CrossRef] [PubMed]

126. Calender, A.; Lim, C.X.; Weichhart, T.; Buisson, A.; Besnard, V.; Rollat-Farnier, P.A.; Bardel, C.; Roy, P.; Cottin, V.; Devouassoux, G.; et al. Exome sequencing and pathogenicity-network analysis of five French families implicate mTOR signalling and autophagy in familial sarcoidosis. Eur. Respir. J. 2019, 54. [CrossRef]

127. Manzia, T.M.; Bellini, M.I.; Corona, L.; Toti, L.; Fratoni, S.; Cillis, A.; Orlando, G.; Tisone, G. Successful treatment of systemic de novo sarcoidosis with cyclosporine discontinuation and provision of rapamune after liver transplantation. Transpl. Int. 2011, 24, e69-e70. [CrossRef] [PubMed]

128. Adcock, I.M.; Barnes, P.J. Molecular mechanisms of corticosteroid resistance. Chest 2008, 134, $394-401$. [CrossRef]

129. Chikanza, I.C.; Kozaci, D.L. Corticosteroid resistance in rheumatoid arthritis: Molecular and cellular perspectives. Rheumatology (Oxford) 2004, 43, 1337-1345. [CrossRef]

130. Farrell, R.J.; Kelleher, D. Glucocorticoid resistance in inflammatory bowel disease. J. Endocrinol. 2003, 178, 339-346. [CrossRef]

131. Maltese, P.; Palma, L.; Sfara, C.; de Rocco, P.; Latiano, A.; Palmieri, O.; Corritore, G.; Annese, V.; Magnani, M. Glucocorticoid resistance in Crohn's disease and ulcerative colitis: An association study investigating GR and FKBP5 gene polymorphisms. Pharm. J. 2012, 12, 432-438. [CrossRef] [PubMed]

132. Oakley, R.H.; Cidlowski, J.A. The biology of the glucocorticoid receptor: New signaling mechanisms in health and disease. J. Allergy Clin. Immunol. 2013, 132, 1033-1044. [CrossRef] [PubMed]

133. Webster, J.C.; Oakley, R.H.; Jewell, C.M.; Cidlowski, J.A. Proinflammatory cytokines regulate human glucocorticoid receptor gene expression and lead to the accumulation of the dominant negative beta isoform: A mechanism for the generation of glucocorticoid resistance. Proc. Natl. Acad. Sci. USA 2001, 98, 6865-6870. [CrossRef] [PubMed]

134. Franchimont, D.; Martens, H.; Hagelstein, M.T.; Louis, E.; Dewe, W.; Chrousos, G.P.; Belaiche, J.; Geenen, V. Tumor necrosis factor alpha decreases, and interleukin-10 increases, the sensitivity of human monocytes to dexamethasone: Potential regulation of the glucocorticoid receptor. J. Clin. Endocrinol. Metab. 1999, 84, 2834-2839.

135. Burdon, R.H.; O'Kane, D.; Fadzillah, N.; Gill, V.; Boyd, P.A.; Finch, R.R. Oxidative stress and responses in Arabidopsis thaliana and Oryza sativa subjected to chilling and salinity stress. Biochem. Soc. Trans. 1996, 24, 469-472. [CrossRef]

136. Webster, J.C.; Huber, R.M.; Hanson, R.L.; Collier, P.M.; Haws, T.F.; Mills, J.K.; Burn, T.C.; Allegretto, E.A. Dexamethasone and tumor necrosis factor-alpha act together to induce the cellular inhibitor of apoptosis-2 gene and prevent apoptosis in a variety of cell types. Endocrinology 2002, 143, 3866-3874. [CrossRef]

137. Stocklin, E.; Wissler, M.; Gouilleux, F.; Groner, B. Functional interactions between Stat5 and the glucocorticoid receptor. Nature 1996, 383, 726-728. [CrossRef] 
138. Goleva, E.; Kisich, K.O.; Leung, D.Y. A role for STAT5 in the pathogenesis of IL-2-induced glucocorticoid resistance. J. Immunol. 2002, 169, 5934-5940. [CrossRef]

139. Zhou, T.; Casanova, N.; Pouladi, N.; Wang, T.; Lussier, Y.; Knox, K.S.; Garcia, J.G.N. Identification of Jak-STAT signaling involvement in sarcoidosis severity via a novel microRNA-regulated peripheral blood mononuclear cell gene signature. Sci. Rep. 2017, 7, 4237. [CrossRef]

140. Rotenberg, C.; Besnard, V.; Brillet, P.Y.; Giraudier, S.; Nunes, H.; Valeyre, D. Dramatic response of refractory sarcoidosis under ruxolitinib in a patient with associated JAK2-mutated polycythemia. Eur. Respir. J. 2018, 52, 1801482. [CrossRef]

141. Delgado-Martin, C.; Meyer, L.K.; Huang, B.J.; Shimano, K.A.; Zinter, M.S.; Nguyen, J.V.; Smith, G.A.; Taunton, J.; Winter, S.S.; Roderick, J.R.; et al. JAK/STAT pathway inhibition overcomes IL7-induced glucocorticoid resistance in a subset of human T-cell acute lymphoblastic leukemias. Leukemia 2017, 31, 2568-2576. [CrossRef]

142. Nishida, T.; Miyata, S.; Itoh, Y.; Mizuki, N.; Ohgami, K.; Shiratori, K.; Ilieva, I.B.; Ohno, S.; Taylor, A.W. Anti-inflammatory effects of alpha-melanocyte-stimulating hormone against rat endotoxin-induced uveitis and the time course of inflammatory agents in aqueous humor. Int. Immunopharmacol. 2004, 4, 1059-1066. [CrossRef] [PubMed]

143. Colombo, G.; Buffa, R.; Bardella, M.T.; Garofalo, L.; Carlin, A.; Lipton, J.M.; Catania, A. Anti-inflammatory effects of alpha-melanocyte-stimulating hormone in celiac intestinal mucosa. Neuroimmunomodulation 2002, 10, 208-216. [CrossRef] [PubMed]

144. Bhardwaj, R.S.; Schwarz, A.; Becher, E.; Mahnke, K.; Aragane, Y.; Schwarz, T.; Luger, T.A. Pro-opiomelanocortin-derived peptides induce IL-10 production in human monocytes. J. Immunol. 1996, 156, 2517-2521. [PubMed]

145. Bhardwaj, R.; Becher, E.; Mahnke, K.; Hartmeyer, M.; Schwarz, T.; Scholzen, T.; Luger, T.A. Evidence for the differential expression of the functional alpha-melanocyte-stimulating hormone receptor MC-1 on human monocytes. J. Immunol. 1997, 158, 3378-3384.

146. Becher, E.; Mahnke, K.; Brzoska, T.; Kalden, D.H.; Grabbe, S.; Luger, T.A. Human peripheral blood-derived dendritic cells express functional melanocortin receptor MC-1R. Ann. N. Y. Acad. Sci. 1999, 885, 188-195. [CrossRef]

147. Ollivier, V.; Parry, G.C.; Cobb, R.R.; de Prost, D.; Mackman, N. Elevated cyclic AMP inhibits NF-kappaB-mediated transcription in human monocytic cells and endothelial cells. J. Biol. Chem. 1996, 271, 20828-20835. [CrossRef]

148. Parry, G.C.; Mackman, N. Role of cyclic AMP response element-binding protein in cyclic AMP inhibition of NF-kappaB-mediated transcription. J. Immunol. 1997, 159, 5450-5456.

149. Buggy, J.J. Binding of alpha-melanocyte-stimulating hormone to its G-protein-coupled receptor on B-lymphocytes activates the Jak/STAT pathway. Biochem. J. 1998, 331 Pt. 1, 211-216. [CrossRef]

150. McPeek, M.; Malur, A.; Tokarz, D.A.; Murray, G.; Barna, B.P.; Thomassen, M.J. PPAR-gamma pathways attenuate pulmonary granuloma formation in a carbon nanotube induced murine model of sarcoidosis. Biochem. Biophys. Res. Commun. 2018, 503, 684-690. [CrossRef]

151. Soliman, R.H.; Ismail, O.A.; Badr, M.S.; Nasr, S.M. Resveratrol ameliorates oxidative stress and organ dysfunction in Schistosoma mansoni infected mice. Exp. Parasitol. 2017, 174, 52-58. [CrossRef] [PubMed]

152. Malaguarnera, L. Influence of Resveratrol on the Immune Response. Nutrients 2019, 11, 946. [CrossRef] [PubMed]

153. Campo, I.; Morbini, P.; Zorzetto, M.; Tinelli, C.; Brunetta, E.; Villa, C.; Bombieri, C.; Cuccia, M.; Agostini, C.; Bozzi, V.; et al. Expression of receptor for advanced glycation end products in sarcoid granulomas. Am. J. Respir. Crit. Care Med. 2007, 175, 498-506. [CrossRef] [PubMed]

154. Bargagli, E.; Magi, B.; Olivieri, C.; Bianchi, N.; Landi, C.; Rottoli, P. Analysis of serum amyloid A in sarcoidosis patients. Respir. Med. 2011, 105, 775-780. [CrossRef]

155. Yan, S.D.; Zhu, H.; Zhu, A.; Golabek, A.; Du, H.; Roher, A.; Yu, J.; Soto, C.; Schmidt, A.M.; Stern, D.; et al. Receptor-dependent cell stress and amyloid accumulation in systemic amyloidosis. Nat. Med. 2000, 6, 643-651. [CrossRef] 
156. Belmokhtar, K.; Robert, T.; Ortillon, J.; Braconnier, A.; Vuiblet, V.; Boulagnon-Rombi, C.; Diebold, M.D.; Pietrement, C.; Schmidt, A.M.; Rieu, P.; et al. Signaling of Serum Amyloid A Through Receptor for Advanced Glycation End Products as a Possible Mechanism for Uremia-Related Atherosclerosis. Arterioscler Thromb. Vasc. Biol. 2016, 36, 800-809. [CrossRef]

157. Crouser, E.D.; Culver, D.A.; Knox, K.S.; Julian, M.W.; Shao, G.; Abraham, S.; Liyanarachchi, S.; Macre, J.E.; Wewers, M.D.; Gavrilin, M.A.; et al. Gene expression profiling identifies MMP-12 and ADAMDEC1 as potential pathogenic mediators of pulmonary sarcoidosis. Am. J. Respir. Crit. Care Med. 2009, 179, 929-938. [CrossRef]

158. Piotrowski, W.J.; Nawrocka-Kunecka, A.; Antczak, A.; Marczak, J.; Biernacki, R.; Kordek, P.; Kurmanowska, Z.; Gorski, P. Metalloproteinases MMP-9, MMP-2 and their tissue inhibitors TIMP-1, TIMP-2 in peripheral transbronchial lung biopsies of patients with sarcoidosis. Pol. Arch. Med. Wewn. 2009, 119, 628-635. [CrossRef]

159. John, M.; Oltmanns, U.; Fietze, I.; Witt, C.; Jung, K. Increased production of matrix metalloproteinase-2 in alveolar macrophages and regulation by interleukin-10 in patients with acute pulmonary sarcoidosis. Exp. Lung Res. 2002, 28, 55-68. [CrossRef]

160. Craig, V.J.; Zhang, L.; Hagood, J.S.; Owen, C.A. Matrix metalloproteinases as therapeutic targets for idiopathic pulmonary fibrosis. Am. J. Respir. Cell Mol. Biol. 2015, 53, 585-600. [CrossRef]

161. Pabst, S.; Franken, T.; Schonau, J.; Stier, S.; Nickenig, G.; Meyer, R.; Skowasch, D.; Grohe, C. Transforming growth factor-\{beta\} gene polymorphisms in different phenotypes of sarcoidosis. Eur. Respir. J. 2011, 38, 169-175. [CrossRef] [PubMed]

162. Patterson, K.C.; Franek, B.S.; Muller-Quernheim, J.; Sperling, A.I.; Sweiss, N.J.; Niewold, T.B. Circulating cytokines in sarcoidosis: Phenotype-specific alterations for fibrotic and non-fibrotic pulmonary disease. Cytokine 2013, 61, 906-911. [CrossRef] [PubMed]

163. Korthagen, N.M.; Nagtegaal, M.M.; van Moorsel, C.H.; Kazemier, K.M.; van den Bosch, J.M.; Grutters, J.C. MRP14 is elevated in the bronchoalveolar lavage fluid of fibrosing interstitial lung diseases. Clin. Exp. Immunol. 2010, 161, 342-347. [CrossRef] [PubMed]

164. Crouser, E.D. In-silico modeling of granulomatous diseases. Curr. Opin. Pulm. Med. 2016, 22, 500-508. [CrossRef]

165. Maertzdorf, J.; Weiner, J., 3rd; Mollenkopf, H.J.; Bauer, T.; Prasse, A.; Muller-Quernheim, J.; Kaufmann, S.H. Common patterns and disease-related signatures in tuberculosis and sarcoidosis. Proc. Natl. Acad. Sci. USA 2012, 109, 7853-7858. [CrossRef]

166. James, W.E.; Baughman, R. Treatment of sarcoidosis: Grading the evidence. Expert Rev. Clin. Pharmacol. 2018, 11, 677-687. [CrossRef]

167. Saketkoo, L.A.; Baughman, R.P. Biologic therapies in the treatment of sarcoidosis. Expert Rev. Clin. Immunol. 2016, 12, 817-825. [CrossRef]

(C) 2020 by the authors. Licensee MDPI, Basel, Switzerland. This article is an open access article distributed under the terms and conditions of the Creative Commons Attribution (CC BY) license (http://creativecommons.org/licenses/by/4.0/). 